\title{
The Whale Man of Newfoundland and Labrador: Jon Lien 1939-2010
}

\author{
Wayne Ledwell, Kristina Curren, Julie Huntington, and Catherine Hood
}

Ledwell, Wayne, Kristina Curren, Julie Huntington, and Catherine Hood, 2010. The Whale Man of Newfoundland and Labrador: Jon Lien 1939-2010. Canadian Field-Naturalist 124(4): 384-398.

Born: 19 March 1939, in Clark, South Dakota, U.S.A.

Died: 14 April 2010, in St. John's, Newfoundland, Canada.

"He is at home behind a podium, in a fishing boat, in the belly of a whale, or in a fisherman's kitchen." Citation for Dr. Jon Lien's Order of Newfoundland and Labrador

Dr. Jon Lien was truly an extraordinary man-he was both a force of nature and larger than life. He was warm-hearted, welcoming, humorous, everlastingly inquisitive, passionate, tireless, indomitable, and incredibly knowledgeable. He loved the land, the sea, the whales, his students, his farm, and his friends and family. Jon knew, better than anyone, how to experience joy and wonder in every moment and how to live life to its fullest. His "joie de vie," his curiosity about everything from the mundane to the arcane, his devotion to cause, and his laughter were infectious. No one who met Jon could remain untouched by or forget him.

\section{The Early Years}

Ordin Jon Lien was the eldest of four children born to Ordin Justus and Alvera Seim. Born in Clark, South Dakota, on 19 March, 1939, Jon grew up during the scarcity and rationing of World War II. He enjoyed a good family life and learned the values of cooperation, community involvement, and respect for elders.

Jon's love for and interest in animals came at an early age. When his youngest sister, Karin, was born, he was asked if he liked the new baby. His reply? "I'd rather a chicken!"

At the age of four years, Jon rescued a baby squirrel whose mother had been run over by a car. He fed it with a doll's baby bottle. When the squirrel grew up and became aggressive, he decided it was time to release it back outdoors. Before doing so, however, he gave the squirrel's tail a crew cut so he could recognize it if it stayed around.

Jon and his good friend, Larry Larrabee, built a canvas-covered canoe from a design in Popular Mechanics, raced push carts constructed from baby carriage wheels, broom handles, and clothes-line rope, competed in soapbox derbies and played a lot of sandlot baseball. In summer they fished for bullheads on their homemade raft in Willow Creek. The fish were always cleaned and donated to the local retirement home.

When he was older, Jon's summers were spent on his uncles' farms working with pigs, cattle, and chickens. One summer day, he came home and announced to his parents that he wanted to raise chickens. With little consultation, 500 baby chicks were delivered to their door and Jon turned the garage into a chicken house. When it came time to sell the chickens in his father's store, the whole family helped with chopping, dipping, and plucking. For a short while, Jon's fresh, home-grown chicken became a popular Sunday dinner meal in his Watertown neighbourhood and garnered a substantial savings for his first year of college.

Friends have said that Jon's youth and teens were dominated by three themes: animals, hard work, and deep thoughts. He carried these themes throughout his life. Jon was mentored by pastors Hinderlie and Bagne in his Lutheran Church in Watertown, South Dakota. He began to read theology (writings of Martin Luther), philosophy, and ecology. Jon was nurtured by his study in the ideals of fairness and equality. He developed a sincere love of nature, and learned to express himself in discussion, debate and writing.

In 1957, Jon chose to attend St. Olaf College, a liberal arts school in Northfield, Minnesota, to study arts and literature. In his second year, his parents moved to Northfield and purchased the Ole Store, a grocery store and café, so that Jon's siblings could also attend St. Olaf College. That year, Jon also met Judy Traastad. They fell in love and married after graduation in 1962.

Jon spent his summers during college working for the Plymouth Canoe Base in the Quetico Wilderness of northern Minnesota. He also took leave in his third year at St. Olaf for a winter assignment at the base. There he worked with troubled youth from the Minneapolis area and decided that psychology would be valuable as an advanced degree.

Jon was accepted for graduate study at Washington State University in Pullman, Washington. In the fall of 1962 he and Judy travelled west to Washington. Judy would teach elementary school and Jon would embark on an advanced degree in clinical psychology. After a great deal of clinical coursework and internship, Jon was attracted to the animal behaviour studies and the depth of Veterinary Science offered at WSU. It became very clear to him that animal behaviour should be his life's work. His chief mentor Dr. Dud Klopfer, a bril- 
liant and complex thinker, brought out the best in Jon. They designed creative research and Jon's disciplined commitment and work ethic brought interesting and valuable results. He was outstanding in his class.

In 1966 Jon and Judy chose their first family pet. A Newfoundland puppy. A serendipitous choice signalling unbeknownst to them, a new course for the couple.

\section{A New Country}

Upon earning his doctorate — his thesis was on the behaviour of the Leach's Storm Petrel — Jon had competing job offers from Hong Kong, Chile, Alberta, and Montreal. After a conference trip to New York City's American Museum of Natural History and the lab of T. C. Schneirla, he was encouraged to apply for a position at Memorial University in Newfoundland. One trip to Newfoundland was enough to make him fall in love with the island, and he accepted a position at Memorial University in 1968. Soon after, as he would often say, the community of Portugal Cove chose him and Judy. A fisherman and neighbour, Joe Miller, found them a six-acre parcel of land that came with a deed from Queen Victoria, and it was there that they established their house and organic farm. The house was hand-built with the help of friends over three weekends, with most of the lumber coming from the old Bowring Salt warehouse on the south side of St. John's. When the Bell Island mine closed, Jon bought the used hardwood flooring from its office and laid it throughout the house. He and Judy dug and rocked the well, put panes in the French window frames throughout the house, plastered the walls and built the fireplaces. Jon attacked each home "making" challenge with joy and enthusiasm!

Jon loved teaching and set up an old barn on Mount Scio Road for offices and research space. He used St. John's Harbour, city ponds, and Conception Bay for his initial work with seabirds. Later, the outlying bays and coastal communities became his laboratories. In each outport and on every project, Jon made friends and good relationships. In 1977 after three years of hearing "strange nocturnal noises" Lien and his students confirmed the only known breeding colony of manx shearwaters Puffinus puffinus in North America on Middle Lawn Island in Placentia Bay.

\section{Whale Research Group}

During the late 1970s, a new problem emerged in Newfoundland and Labrador waters. In their search for food, humpback whales were colliding with and becoming entangled in the fishing gear of inshore fisherman. In 1978, Jon received a call from fishermen about a humpback whale that had been entangled in a net for several months and was gradually starving. Jon arrived on the scene and managed to release the animal. It wasn't long before other fishermen in the same predicament were calling him.

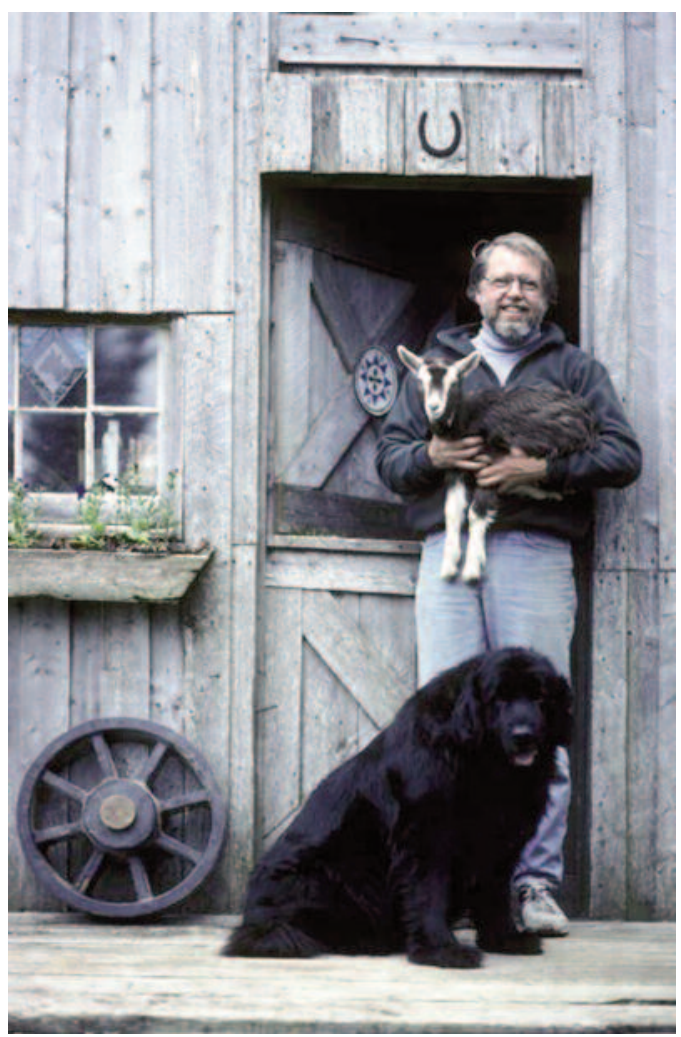

FIGURE 1. Jon Lien at home in Newfoundland outside his barn with his Newfoundland dog Jenny and a goat kid.

It was the beginning of his destiny: Jon secured a small government research grant and founded the Whale Research Group, the principle focus of which was the Entrapment Assistance Program. Whales tangled in fishing nets were a significant problem for both the animals and men. Previously, the entrapped whale often died, and the fishermen who owned the ruined nets suffered serious financial losses and lost their chance at earning an income for their family for a part or all of the short fishing season. The Entrapment Assistance Program offered technical assistance and services to fishermen and entrapped animals across the province. Fishermen responded and found at last that they had a committed partner to assist them with this problem. At its peak, the program dealt with 150 entrapped humpbacks each year and 11 different species of whales and dolphins were safely released from fishing gear. The Whale Research Group also ran an educational program for schools.

As the leader of the Whale Research Group, Jon became passionately committed to marine environment conservation as well as the welfare of fishermen. He had a trusted relationship with a fishing community that generally regarded scientists with suspicion, and 
he was at the forefront of a new generation of fisheries researchers who learned to work with fishermen rather than work around them. Jon is credited with saving hundreds of whales trapped in fishing gear, but he always considered the "endangered fisherman" as well, helping them to haul in and mend their nets after an entanglement and encouraging them to tell their story.

Jon was one of the first researchers to use an ecosystem approach to whale conservation. His understanding that whales, fish stocks, seabirds, and fishermen were all inexorably linked both ecologically and economically was radically different from the single-species management blueprint of the day. He invented a series of alarm systems including the "Lien pinger" to warn whales away from fishing nets and prevent entrapments, and he pioneered entanglement rescue techniques that are now used all over the world. His work earned him unequalled respect from both fishermen and scientists around the globe.

Education was always a main focus for Jon, and graduate students from across Canada and the United States, England, Brazil, Argentina, and Germany applied to work with and be mentored by the "Whale Man.” He was unfailingly generous with his students, offering them beds in his cabin if they had no place to stay, finding scholarship money for them, and helping them to publish their work in scientific journals. His encouragement of academic excellence and practical knowledge gained through hands-on experience transformed his graduate students into independent and motivated researchers.

\section{Environmental Conservation}

Jon's professional life expanded in the late 1980s: he helped establish new policies through the International Whaling Commission; he shared his ideas and counsel through speaking engagements throughout the world; he cooperated in various studies in Australia, Holland, China, Brazil, Trinidad, Indonesia, and the United States; and after visiting marine aquariums around the world, he completed a major report titled "Cetaceans in Captivity" for the Canadian government. He believed that ordinary people should have contact with whales and the sea, and he worked with tour boat operators to create a Code of Conduct for Whale Watching in Newfoundland's coastal waters.

Jon was passionate about environmental conservation. He helped to create, guide, and work on behalf of the National Parks and Marine Protected Areas, the Canadian Parks and Wilderness Society's Newfoundland and Labrador Chapter, the Protected Areas Association of Newfoundland and Labrador, and the Torngat Mountains National Park.

Jon was also an active member of many provincial, national, and international organizations and committees. These included the Department of Fisheries and Oceans' Minister's Advisory Committee on Oceans, the Terra Nova Development Project Environmental

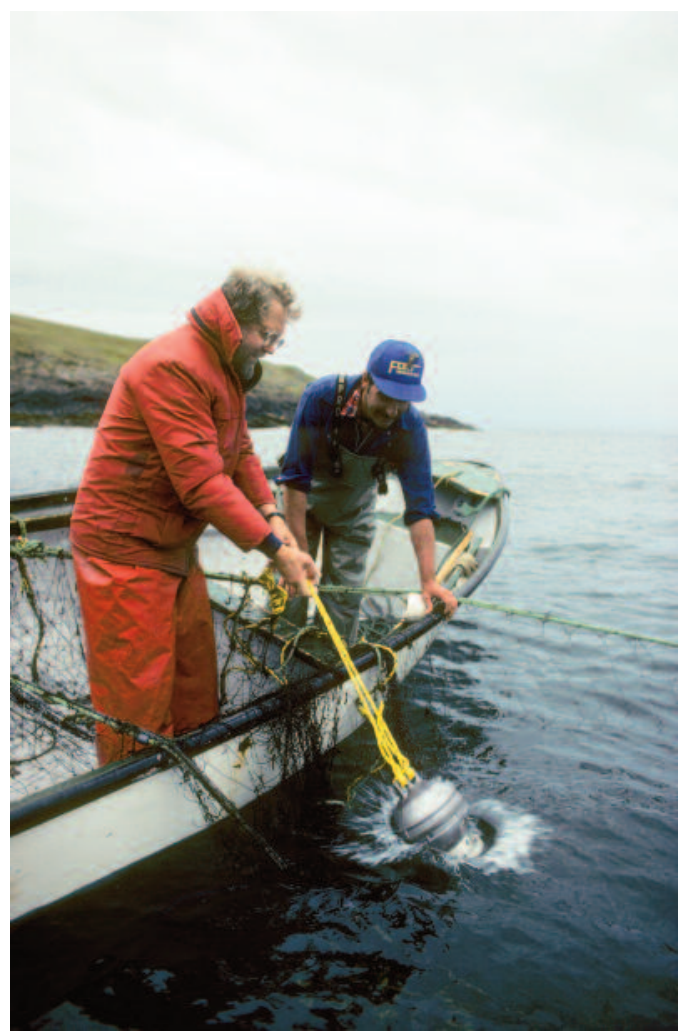

FIGURE 2. Jon Lien attaches whale alarma to a cod net.

Assessment Panel, the International Union for Conservation of Nature Commission on National Parks and Protected Areas, the Fisheries National Roundtable on the Environment and the Economy, and the Fisheries Resource Conservation Council. He also spent time at the United Nations working on Law of the Sea policy.

For his work, Jon was awarded the Order of Canada, the Order of Newfoundland and Labrador, the $125^{\text {th }}$ Anniversary of the Confederation of Canada Commemorative Medal, the Lifetime Achievement Award from the Newfoundland and Labrador Department of Environment and Conservation, the Keyes Award for Research and Conservation, the Department of Fisheries and Oceans' Deputy Minister's Award, the World Environment Day Award, and an Honorary Doctor of Science from St. Olaf College.

\section{"Jon Stories"}

Jon left a zodiac full of stories wherever he worked and those stories took shape immediately when people got together who had worked with him. Like a cat, Jon seemed to have nine lives. One brush with death took place in Australia while assisting scientists with whale and shark deterrents. He was helping a friend 
bait shark hooks along a stretch of shoreline known for shark attacks and where a swimmer had been taken just days before. When the automatic trawl line full of hooks advanced, Jon's hand was hooked and he was pulled off the boat. The skipper of the boat jumped in after him and the boat sped off with a mind of its own. "I'll make it!" Jon assured the skipper. He cut the trawl line with his Swiss army knife to free himself, got rid of his shoes, and swam a full mile back to shore, bleeding, dragging a buoy, and with the shark hook still embedded in his palm. The jaws of life were needed to cut through and remove the hook from his hand, and Jon escaped with a treatable tropical infection.

Then there was the capsizing of his zodiac off Lords Cove on the Burin Peninsula of Newfoundland. He managed to hold onto the boat and showed up in the community in the early morning looking to rinse the engine with fresh water on a day when it was too rough for inshore fishermen to go fishing. There was the time another scientist aboard a fishing boat off Red Island in Placentia Bay came upon a radar target in thick fog. The first question was "Do you have shear pin for a 25 Johnson". It was Jon and a student in a zodiac - broke down.

Then there was Jon's trip to Toronto in the 1970s for a specialized procedure to repair and stabilize a collapsed lung. Just released from the hospital, he called Judy to wire money to Toronto because he wanted a goat breeder at the Royal Winter Fair to sell him some dairy goats. He succeeded in buying the goats, built the shipping crates himself to contain all 12 , and hitched a ride in the cockpit with the pilots while they freighted the goats back to Newfoundland. And the stories could go on and on and on.

\section{Lien Family Farm}

Jon loved farming. When he and Judy bought their land in Portugal Cove, he immediately planted a garden, began working to improve the soil, and constructed the greenhouses that he knew would extend the short Newfoundland 60 day growing season. Over the years, he added a barn and paddock, a root cellar, a tractor shed, a cabin, and a two-storey chill building. He hauled thousands of bags of leaves, manure, and sawdust and dump truck loads of peat to create fertile ground. An organic inspector who certified farms from Ontario to Newfoundland declared that the soil at the Lien Family Farm was more productive per square foot than any other soil she'd ever seen.

The Lien family raised goats, chickens, turkeys, and pigs and produced more than 50 different crops for the Organic Veggie Co-op/Lien Farm Share CSAs supplying local families and a St. John's health food store. On Thanksgiving 2002, the Lien Family Farm celebrated its 30th anniversary. Today, the land is still worked organically by a group of young farmers who sell their produce in community shares.

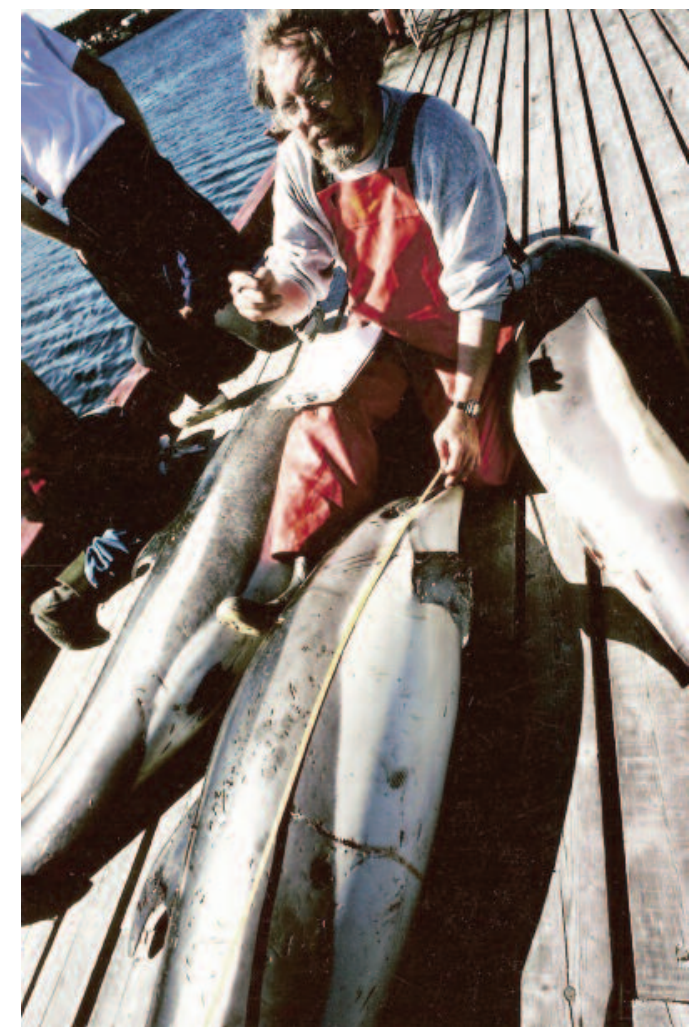

FIGURE 3. Jon Lien recording data on dolphins.

\section{Later Life}

On 16 October 2002, Jon was involved in a truck accident that changed his life with a refocus on his personal health. Nevertheless, in 2003-2004 he helped to complete a study encouraging a sustainable lobster fishery in Eastport, Bonavista Bay. He determinedly helped with chores on the farm, and he sought out, purchased, and began working a tract of land in central Newfoundland.

Over the next few years, Jon's mobility became increasingly difficult and daily tasks became a challenge. Jon was hospitalized in 2007, requiring full-time nursing home care. Judy remained a steadfast companion until his death.

On Wednesday, 14 April 2010, at the age of 71, Jon died of heart complications. Jon was predeceased in death by his parents and sister Mary (Lien) Wilson. He is survived by his wife Judy (Traastad) Lien, sister Karin (Lien) Watson, brother Richard Lien, daughter Maren (Lien) Hinlopen, sons O. J. Lien and Elling Lien, and grandchildren Teya and Talia Hinlopen and Ellen Ann Lien.

Jon Lien's was a life well lived, well loved, and will not be forgotten. 


\section{Publications of Jon Lien 1967-2010}

Lien, O. J. 1967. Some relations between suckling stereotypy, exploratory behaviour, and discrimination reversals in swine. Master's thesis. Washington State University.

Lien, J., and H. Barbaree. 1970. Prenatal patterned auditory stimulation and its effect on the post-hatch approach response in domestic chicken (Gallus gallus domesticus). Paper Presented to the Annual Meeting of the Canadian Psychological Association, Winnipeg, May 28.

Lien, J. 1971. The development of species recognition in avians. Paper presented at Department of Entomology, McGill University, March 30.

Martin, G., M. Parsons, and J. Lien. 1971. Control of sea gulls in city water reservoirs: a preliminary report submitted to the Clean Air, Water and Soil Authority, Government of Newfoundland, April 2.

Lien, J. 1972. Adjusted developmental rates in embryonogeny and embryo acoustic behaviour in several species of nidifugous birds. Dissertation Abstracts International.

Noseworthy, C., S. Stoker, and J. Lien. 1973. Habitat preferences in herring gull chicks. The Auk 90(1): 193-194.

Lien, J., and G. J. Fitzgerald. 1973. Several factors influencing web-spinning activity in the common house spider (Achaearanea tepidariorum Rech. Animal Learning and Behaviour 1(4): 290-292.

Lien, J. 1975. Aggression between Great Black-Backed Gulls and Bald Eagles. The Auk 92(3): 584-585.

Lien, J., and M. Clements. 1975. Effects of tactile stimulation on the initiation and maintenance of the following response in Japanese quail (Coturnix coturnix japonica). Animal Learning and Behavior 3(4): 301-304.

Clements, M., and J. Lien. 1976. Paired rotation and auditory stimulation of common murre Uria alge alge embryos and its posthatch effect. Behavioral Biology 17(3) 417-423.

Lien, J. 1976. Auditory stimulation of Coturnix embryos Coturnix coturnix japonica and its later effect on auditory preferences. Behavioral Biology 17(2): 231-235.

Noseworthy, C. M., and J. Lien. 1976. Ontogeny of nesting habitat recognition and preference in neonatal herring gull chicks, Larus argentatus Pontoppidan. Animal Behaviour 24(3): 637-651.

Lien, J., and P. Redmond. 1977. Recognition of conspecific vocalization by Coturnix chicks. Quail Quarterly: April.

Lien, J. 1977. Vocalization in Leach's storm petrel [abstract]. American Zoologist.

Lien, J. 1978. Red Island - A study in adaptation of gulls and people. The Osprey (Newfoundland Natural History Society Quarterly) 8(1): 41-47.

Lien, J. 1978. The ugly goatling. The Osprey (Newfoundland Natural History Society Quarterly) 9(3): 85-87.

Lien, J., and L. Grimmer. 1978. Manx shearwater breeding in Newfoundland. The Osprey (Newfoundland Natural History Society Quarterly) 9:50-54.

J. Lien, and F. D. Klopfer. 1978. Some relations between stereotyped suckling in piglets and exploratory behaviour and discrimination reversal learning in adult swine. Applied Animal Ethology 4(3): 223-233.

Lien, J. 1979. Whale collisions with fishing gear in Newfoundland. Report to the Minister's Committee on Whales and Whaling. Government of Canada.

Lien, J., S. Johnson, and B. Merdsoy. 1979. Whale distribution in Newfoundland during 1979. The Osprey 11(2): 21-32.
Lien, J., B. Merdsoy, and A. Storey. 1979. An extralimital record of a Narwhal (Monodon monoceros) in Hall's Bay Newfoundland. Canadian Field-Naturalist 93: 303-304.

Lien, J. 1979. Raising moose calves on dairy goats. Dairy Goat Guide (1): April

Lien, J., and B. Merdsoy. 1979. The humpback is not over the hump. Natural History, April: 46-49.

Lien, J. 1979. Doe mothered a moose nicely. Dairy Goat Guide, April.

Lien, J. 1980. Whale collisions with fishing gear in Newfoundland. Report to Fisheries and Oceans Canada Newfoundland Region. 31 December 1980. 316 pages.

Lien, J. 1980. Cetaceans. Science 208(4441): 279-280.

Lien, J. 1980. Net loss. Nature Canada 9(3): 5-9.

Lien, J., and W. E. Mercer. 1980. Control of lynx predation on caribou calves by flavor illness aversions. Edited by E. Reimers, E. Gaare, and S. Skenneberg in International Reindeer/Caribou Symposium (2): 725-727.

Lien, J., S. Johnson, B. Davis, and S. Gray. 1981. Humpback whale collisions with inshore fishing gear. Preliminary report to Fisheries and Oceans Canada - Newfoundland Region, St. John's, Newfoundland.

Lien, J. 1981. The trouble with whales. Toronto: Greey de Pencier Books. (children's book)

Lien, J., and N. Hennessey. 1982. Whales of Newfoundland and Labrador. St. John's, Newfoundland: MUN Press.

Lien, J., and D. Aldrich. 1982. The basking shark (Cetorhinus maximus) in Newfoundland. Report to the Department of Fisheries, Government of Newfoundland and Labrador, St. John's, Newfoundland. 186 pages.

Lien J., J. H. Dong, L. Baraff, J. Harvey, and K. Chu. 1982. Whale entrapment in inshore fishing gear during 1982: A preliminary report to Fisheries and Oceans Canada, St. John's, Newfoundland. 36 pages.

Lien, J., S. Staniforth, L. Fawcett, R. Vaughan, and D. J. Hai. 1982. Whale and shark entrapments in inshore fishing gear during 1983. Report to Fisheries and Oceans Canada - Newfoundland Region.

Whitehead, H., and J. Lien. 1982. Changes in abundance of whales and whale damage along the Newfoundland coast 1973-1981. International Whaling Commission, Scientific Document SC/ 34/01.

Lien, J., and H. Whitehead. 1983. Changes in humpback (Megaptera novaeangeliae) abundance off NE Newfoundland related to the status of capelin (Mallotus villosus) stocks. In Proceedings of the Fifth Biennial Conference on the Biology of Marine Mammals. Boston, Massachusetts.

Lien, J., and H. Whitehead. 1984. Humpback abundance on NE Newfoundland, whale damage to fishing gear and variation in capelin stocks (1973-1983). In Marine Mammal/Commercial Fisheries Interactions in the SE Bering Sea. Edited by B. Meltoff.

Lien, J., L. Dix, E. Lee, and H. Walter. 1984. Whale and shark entrapments in inshore fishing gear during 1984. Report to Fisheries and Oceans Canada - Newfoundland Region.

Lien, J. (and others of the Whale Research Group). 1984. Getting along: fish, whales and fishermen. St. John's: Breakwater Books.

Lien, J. (and others of the Whale Research Group). 1984. Getting Along: Teacher's Guide. St. John's: Breakwater Books. 
Lien, J. (and others of the Whale Research Group). 1984. Getting Along: Enrichment Kit Teacher's Guide. St. John's: Department of Education, Government of Nefoundland and Labrador.

Lien, J., L. Fawcett, and S. Staniforth. 1984. Whales and seals of Newfoundland and Labrador. St. John's: Breakwater Books.

Lien, J. 1985. Incidental catches of harp seal by inshore fishermen in Newfoundland. Royal Commission on Seals and the Sealing Industry in Canada. 3 pages.

Lein, J. 1985. Incidental occurrence and catches of Leatherback Turtles in Newfoundland (1979-1985). Report to Fisheries and Oceans Canada. 5 pages.

Lein, J. 1985. Review of the preliminary management plan of the Avalon Wilderness Area. Wilderness and Ecological Reserves Advisory Council. Government of Newfoundland and Labrador. 8 pages.

Lein, J. 1985. Review of the management proposal for Mistaken Point. Wilderness and Ecological Reserves Advisory Council, Government of Newfoundland and Labrador. 8 pages.

Lein, J. 1985. Review of the management proposal for "The Grass." Wilderness and Ecological Reserves Advisory Council, Government of Newfoundland and Labrador. 3 pages.

Lein, J. 1985. Review of the management proposal for King George IV Lake Delta. Wilderness and Ecological Reserves Advisory Council, Government of Newfoundland and Labrador. 5 pages.

Lein, J. 1985. Review of the management proposal for the Avalon Wilderness Area. Wilderness and Ecological Reserves Advisory Council, Government of Newfoundland and Labrador. 6 pages.

Lien, J., J. Au, J. Connley, S. Greening, and B. Stirling. 1985. Attitudes toward the environment and their implications for wilderness preservation in Newfoundland. Park News 21(4): 8-13.

Lien, J., and L. Fawcett. 1985. A contribution to the biology of the basking shark (Cetorhinus maximus) in waters off Newfoundland. Canadian Field-Naturalist 100: 246-252.

Lien, J., L. Fawcett, and S. Staniforth. 1985. Teaching fishermen about whales: The role of education in conservation and fisheries management problems. In Marine Parks and Conservation, Volume 1. Edited by J. Lien. and R. Graham. National and Provincial Parks Association of Canada, Toronto, Ontario.

Lien, J., and R. Graham. 1985. An introduction to marine parks and conservation. In Marine Parks and Conservation, Volume 1. Edited by J. Lien and R. Graham. National and Provincial Parks Association of Canada, Toronto, Ontario.

Lien, J., D. Snow, G. B. Stenson, and R. Elliot. 1985. Incidental entrapment of whales, seals, and seabirds in inshore fishing gear in Newfoundland and Labrador: A problem for fishermen and fishing gear designers. World Symposium on Fishing Gear and Fishing Vessel Design, November 21-24, St. John's, Newfoundland.

Lien, J., S. Staniforth, and L. Fawcett. 1985. Teaching fishermen about whales: The role of education in conservation and fisheries management problems. In Marine Parks and Conservation, Volume 1. Edited by J. Lien and R. Graham. National and Provincial Parks Association of Canada, Toronto, Ontario.

Lien J., G. B. Stenson, and I. Hsun Ni. 1985. A review of incidental entrapment of whales, seals and seabirds in inshore fishing gear in Newfoundland and Labrador: A problem for fishermen and fishing gear designers. World Symposium on Fishing Gear and Fishing Vessel Design, November 21-24, St. John's, Newfoundland.

Lien, J., and H. Walter. 1985. An investigation of the potential role of education in managing marine resource conflicts: Volume I. Report to Communications Directorate, Fisheries and Oceans Canada. 530 pages.

Lien, J. 1985. Marine education in Canada: An investigation of the potential role of education in managing marine resource conflicts. Volume 1, Final Report to the Department of Fisheries and Oceans, Contract Number 0ST8400119, Ottawa.

Lien, J., H. Walter, and C. Harvey-Clark. 1985. Whale and shark entrapments in inshore fishing gear during 1985. Report to Fisheries and Oceans Canada-Newfoundland Region and the Newfoundland and Labrador Department of Fisheries. 21 pages.

Storey, A. E., and J. Lien. 1985. Development of the first North American colony of Manx Shearwaters. Auk 102(2): 395-401.

Walter, H., and J. Lien. 1985. Knowledge and attitudes of Canadian students and teachers towards the marine environment and marine education. In Marine Parks and Conservation, Volume 1. Edited by J. Lien and R. Graham. National and Provincial Parks Association of Canada, Toronto, Ontario.

Lien, J. 1985. Managing Whale / Fishermen conflicts. In proceedings of the whale entrapment workshop, National Marine Fisheries Service, San Padro, California.

Lien, J., and R. Graham. Editors. 1985. Marine parks and conservation: challenge and promise, Volume 1: Issues. Harkin Park book series number 10. Toronto: National and Provincial Parks Association of Canada.

Lien, J., and R. Graham. Editors. 1985. Marine parks and conservation: challenge and promise, Volume 2: International experience. Harkin Park book series no. 11. Toronto: National and Provincial Parks Association of Canada.

Lien, J., and R. Graham. Editors. 1986. Marine parks and conservation: challenge and promise, Volume 3: International experience. Harkin Park book series number 12 . Toronto: National and Provincial Parks Association of Canada.

Dix, L., J. Lien, and D. E. Sergeant. 1986. A North Sea Beaked Whale (Mesoplodon bidens) in Conception Bay, Newfoundland. Canadian Field-Naturalist 100: 389-391.

Lien, J. 1986. Teaching fishermen about whales. Whalewatcher 20:3-7.

Lien, J. 1986 Social science and conservation perspectives in integrated forest land use. The Forester 22(3): 1986.

Lien, J. 1986. Prescribed and optional environmental education in provincial curriculum guides. Report to the Canadian Nature Federation. 4 pages.

Lien, J. 1986. Blue whales stranded due to ice on Newfoundland's southwest coast (1978-1986). Fisheries and Oceans Canada. 11 pages.

Lien, J., and K. Breeck. 1986. Marine mammal sightings on the Gadus Atlantica, 13 May-2 June, 1986. Fisheries and Oceans Canada. 11 pages.

Lien, J., K. Breeck, D. Pinsent, and H. Walter. 1986. Whale and shark entrapments in inshore fishing gear during 1986. Report to Fisheries and Oceans Canada - Newfoundland Region. 26 pages.

Lien, J., and L. Fawcett. 1986. Distribution of Basking Sharks (Cetorhinus maximus) incidentally caught in inshore 
fishing gear in Newfoundland. Canadian Field-Naturalist 100: 246-252.

Lien, J., and D. Pinsent. 1986. Whale abundance in standard transects on Newfoundland's northeast coast during 1986. Fisheries and Oceans Canada 8 pages.

Lien, J. 1986. Review of "The war against the seals, a history of the North American Seal Fishery" by Briton Cooper Bushe in The American Review of Canadian Studies.

Lien, J., and H. Walter. 1986. Life along the edge: where land and sea interact. Teacher's guide for grade 4-6 curricula. Ottawa: Parks Canada.

Lien, J. 1987. Vocalizations in humpback whales when they're all alone. Abstracts of the Seventh Biennial Conference on the Biology of Marine Mammals, Society for Marine Mammalogy.

Lien, J. 1987. Can we teach everybody to feel the same way about whales? Abstracts of the Seventh Biennial Conference on the Biology of Marine Mammals, Society for Marine Mammalogy.

Lien, J., and K. Breeck. 1987. Cetacean strandings in Newfoundland and Labrador and geomagnetic characteristics of stranding locations. North Atlantic Marine Mammal Association Proceedings of Meetings, NAMMA, Provincetown, Mass.

Lien, J., K. Breeck, D. Pinset, and H. Walter. 1987. Humpback whale collisions with inshore fishing gear in Newfoundland and Labrador (1978-1986). North Atlantic Marine Mammal Association Proceedings of Meetings, NAMMA, Provincetown, Mass.

Lien, J., K. Breeck, and G. B. Stenson. 1987. A mass stranding of Sowerby's beaked whales (Mesoplodon bidens) in Newfoundland. North Atlantic Marine Mammal Association Proceedings of Meetings, NAMMA, Provincetown, Mass.

Lien, J., B. Brown, J. Dodd, and H. Walter. 1987. Cultural relativism and the management of whales. North Atlantic Marine Mammal Association Proceedings of Meetings, NAMMA, Provincetown, Massachusetts.

Lien, J., I. Christensen, and M. Lien. 1987. Observations on the identification of Killer Whales (Orcinus orca) in the Lofoton Islands area of Norway. Report to Hubbs Marine Research Center and I.W.C. Orca Workshop. NAKW/87/04. 11 pages.

Lien, J., J. Papineau, and L. Dugan. 1987. Incidental entrapments of cetaceans, sharks, and marine turtles in inshore fishing gear reported during 1987 in Newfoundland and Labrador. Report to Fisheries and Oceans Canada-Newfoundland Region and the Newfoundland and Labrador Department of Fisheries. 25 pages.

Lien, J., and R. Sears. 1987. Whales and fishermen. Proceedings of the World's Whales Workshop, American Cetacean Society, San Pedro, California.

Lien, J., G. B. Stenson, S. Booth, and R. Sears. 1987. Ice entrapments of blue whales (Balaenoptera musculus) in Newfoundland and Labrador (1978-1987). Abstracts from the North Atlantic Marine Mammal Association Conference, March 26-27, 1987, Boston, Massachusetts.

Lien, J., G. B. Stenson, and P. Jones. 1987. Orca in waters off Newfoundland and Labrador. Report to Hubbs Marine Research Center and I.W.C. Orca Workshop. NAKW/87/ 11. 19 pages.

Kirkham, I. R., W. A. Montevecchi, O. J. Lien, B. O. Sklepkovych, and R. J. Butler. 1987. Damage to Leach's Storm-petrel feet. Ornis Scandinavica 18(1): 61-64.
Goff, G. P., and J. Lien. 1988. Atlantic Leatherback Turtles, Dermochelys coriacea, in cold water off Newfoundland and Labrador. Canadian Field Naturalist 102 (1):1-5.

Lien, J. 1988. A review of the West Isles feasibility study: A study to assess the feasibility of establishing a National Marine Park in the West Isles area of the Bay of Fundy, New Brunswick. Environment Canada-Canadian Parks Service.

Lien, J. 1988. Entrapment assistance program review. Report submitted to the Program Review Committee, Minister's Advisory Committee on Whales and Whaling, Department of Fisheries and Oceans. 6 pages.

Lien, J. 1988. How, when and why to involve fishermen in the park management process. Proceedings of the Workshop on National Marine Park Planning, Hull, Quebec, 23-25 February, Parks Canada, Hull, Quebec. Pages 36-49.

Lien, J. 1988. Lessons from whales and fishermen about marine parks. Pages 36-39 in Occasional Paper 8, Marine, Lake and Coastal Heritage. Edited by R.Graham. Heritage Resources Centre, University of Waterloo, Waterloo, Ontario,

Lien, J. 1988. Problems of Newfoundland fishermen with large whales and sharks during 1987 and a review of incidental entrapment in inshore fishing gear during the past decade. The Osprey 19(1): 30-38 and 19(2): 65-72.

Lien, J. 1988. Great Barrier Reef wonderland: A review of the Great Barrier Reef Marine Park Authority's aquarium. Great Barrier Reef Marine Park Authority, Townsville, Australia. 21 pages.

Lien, J., and J. Atkinson. 1988. Education programmes about whales. Pages 160-169 in The World's Whales: A Closer look. Selected Papers of the Third Biennial Conference and Symposium, Monterey, California, 11-13 November 1988 .

Lien, J. 1988. Canadian lobster fishermen reap the benefits of marine reserves. Waves 5(3): 16.

Lien, J., I. Christensen, M. Lien, and P. Jones. 1988. A note on Killer whales (Orcinus orca) near Svolvær, Lofoten Islands, Norway, in November-December 1984. Rit Fiskideildar 11: 95-98.

Lien, J., W. Ledwell, and J. Naven. 1988. Incidental entrapments in inshore fishing gear during 1988: Report to the Newfoundland and Labrador Department of Fisheries and Oceans Canada-Newfoundland Region and the Newfoundland and Labrador Department of Fisheries. 38 pages.

Lien, J., and D. Snow. 1988. A new record of a white shark in Newfoundland. The Osprey 19(2): 12-15.

Lien, J., and D. Snow. 1988. Bay du Nord Wilderness. Borealis 1(1): 31-35.

Lien, J., G. B. Stenson, and I.-H. Ni. 1988. A review of incidental entrapment of seabirds, seals, and whales in inshore fishing gear in Newfoundland and Labrador: A problem for fishermen and fishing gear designers. Proceedings of the 1988 World Symposium on Fishing Gear and Fishing Vessel Design. Newfoundland and Labrabdor Institute of Fisheries and Marine Technology, St. Johns's. Newfoundland. Pages 67-71.

Lien, J., G. B. Stenson, and P. W. Jones. 1988. Killer whales (Orcinus orca) in waters off Newfoundland and Labrador, 1978-1986. Rit Fiskideildar 11: 194-201.

Árnason, Ú., P. W. Allderdice, J. Lien, and B. Widegren. 1988. Highly repetitive DNA in the baleen whale genera Balaenoptera and Megaptera. Journal of Molecular Evolution 27: 217-221. 
Muir, D. C. G., R. Wagemann, N. P. Grift, R. J. Norstrom, M. Simon, and J. Lien. 1988. Organochlorine and heavy metal contaminants in white-beaked dolphins (Lagenorhynchus albirostris) and pilot whales (Globicephala melaena) from the coast of Newfoundland, Canada. Archives of Environment Contamination and Toxicology 17: 613-629.

Lien, J. 1989. Incidental catches of Harbour Porpoise (Phocoena phocoena) in waters off Newfoundland and Labrador: Some estimates based on present data and a request for further study. Special Workshop on Harbour Porpoise, St. Andrews, New Brunswick. 8 pages.

Lien, J. 1989. Lessons about whale management. Proceedings of the 5th International Conference on the Relationships Between Humans and Animals, AFRIC, Paris.

Lien, J. 1989. Marine education in Canada - Lessons for marine educators. Pages 1-8 in Proceedings of Splash '89 - Marine interpretation. Ocean Sciences Centre, Memorial University of Newfoundland, St. John's.

Lien, J. 1989. Eau Canada! A new marine-parks system. Pages 107-119 in Endangered Spaces: The Future For Canada's Wilderness. Edited by M. Hummel. Key Porter Books, Toronto, Ontario.

Lien, J. 1989. Eau Canada! How much we have to learn. Pages 1-11 in Interpreting our marine and freshwater heritage. Edited by H. Griffin. Interpretation Canada, Ottawa, Ontario.

Lien, J., and F. Barry. 1989. COSWEIC status report on the Sowerby's beaked whale, Mesoplodon bidens, in Canada. Committee on the Status of Endangered Wildlife in Canada. Ottawa. 20 pages.

Lien, J., and S. Katona. 1989. A guide to the photographic identification of individual whales based on their natural and acquired Markings. American Cetacean Society and Breakwater Books, San Pedro, California. 78 pages.

Lien, J., W. Ledwell, and J. Huntington. 1989. Incidental entrapments in inshore fishing gear reported in 1989. Report to the Department of Fisheries and Oceans-Newfoundland Region and the Newfoundland and Labrador Department of Fisheries. 33 pages.

Lien, J., and P. Parsons. 1989. Working with fishermen and whales. Sonar, 3-7.

Lien, J., and A. Ross. 1989. You oughta be in pictures: Media, marine mammals and mammalogists. North Atlantic Marine Mammal Association Newsletter, Fall, 1989.

Lien, J., R. Sears, G. B. Stenson, P. W. Jones, and I.-H. Ni. 1989. Right whale, Eubalaena glacialis, sightings in waters off Newfoundland and Labrador and the Gulf of St. Lawrence, 1978-1987. Canadian Field-Naturalist 103(1): 91-93.

Lien, J., G. B. Stenson, S. Todd, and I.-H. Ni. 1989. Incidental catches of marine mammals in inshore waters of Newfoundland and Labrador (1979-1989). Abstracts of the 8th Biennial Conference on the Biology of Marine Mammals. 7-11 December, Pacific Grove, California. Page 38.

Lien, J., and W. Ledwell. 1989. Continued Development of the First North American Colony of Manx Shearwaters. The Natural History Society of Newfoundland and Labrador, The Osprey 20(3), September.1989, St. John's, Newfoundland.

Harrigan-Ostrom, P., J. Lien, and S.A. Mako. 1989. Trophic position, feeding habits, and distribution in the Northwest Atlantic of Sowerby's beaked whale, Mesoploden bidens, obtained from carbon and nitrogen isotope data. Abstracts of the 8th Biennial Conference on the Biology of Marine Mammals. 7-11 December, Pacific Grove, California.
Bose, N., and J. Lien. 1989. Propulsion of a fin whale (Balaenoptera physalus): Why the fin whale is a fast swimmer. Proceedings of the Royal Society of London. Series B, Biological Sciences 237(1287), 175-200.

Bose, N., and J. Lien. 1989. A free ride for cetaceans. Abstracts of the $8^{\text {th }}$ Biennial Conference on the Biology of Marine Mammals, 7-11 December, Pacific Grove, California.

Ross, A., and J. Lien. 1989. Ice-entrapped whales: A preliminary analysis of media impact on attitudes and knowledge. Proceedings of the Fifth International Conference on the Relationship Between Humans and Animals, AFRIC, Paris.

Ross, A., and J. Lien. 1989. Ice-entrapped gray whales off Barrows, Alaska: An analysis of media impact on management of cetaceans and public attitudes and knowledge. Abstracts of the 8th Biennial Conference on the Biology of Marine Mammals, 7-11 December, Pacific Grove, California.

Ross, A., J. Lien, and P. Parsons. 1989. Why people like whales. Whalewatcher: Journal of the American Cetacean Society, 23(3) 21-23.

Guigné, J. Y., J. Lien, J. A. Guzzwell, and A. Smith. 1990. Development of acoustic protection for fixed fishing gear to minimize incidental catches of marine mammals. Second Interim Progress Report for the ..., 1990/

Lien, J. 1990. A review of the educational benefits of the Great Barrier Reef Aquarium, Report to the Great Barrier Reef Marine Park Authority, Townsville, Queensland, Australia.

Lien, J. 1990. The inshore cod fishery of Newfoundland and Labrador, Visions 2020, Public Focus, Toronto, Ontario, 27-32.

Lien, J. 1990. Whales of Labrador: Then and now. In Euskaldunen Labrador, de los vascos, des basques. Edited by Xabi Otero. Navarre: Txoria Errekan.

Lien, J. 1990. Whaling in the North Atlantic. Report to the Newfoundland and Labrador Department of Fisheries. 10 pages.

Lien, J. 1990. Review of the adequacy of the environmental impact assessment study for the Goose Bay NATO Base, with particular reference to impacts on marine mammals. 15 pages.

Lien, J., and F. Barry. 1990. Status of Sowerby's beaked whale, Mesoplodon bidens, in Canada. Canadian FieldNaturalist 104(1): 125-130.

Lien, J., F. Barry, K. Breeck, and U. Zuschlag. 1990. Multiple strandings of Sowerby's beaked whales, Mesoplodon bidens, in Newfoundland. Canadian Field-Naturalist 104(3): 414-420.

Lien, J., J. Huntington, W. Ledwell, and T. Huntsman. 1990. Whale entrapments in inshore fishing gear and a summary of the entrapment assistance program in Newfoundland and Labrador during 1990. Report to Fisheries and Oceans Canada-Newfoundland Region and the Newfoundland and Labrador Department of Fisheries. 36 pages.

Lien, J., and S. Katona. 1990. A guide to the photographic identification of individual whales based on their natural and acquired markings. Breakwater Books, St. John's, Newfoundland.

Lien, J., G. B. Stenson, and P. W. Jones. 1990. A natural trap for blue whales Balaenoptera musculus: Sightings and ice entrapments in Newfoundland (1979-1988). Unpublished manuscript.

Lien, J., S. Todd, and J. Guigné. 1990. Inferences about perception in large cetaceans, especially humpback whales, 
from incidental catches in fixed fishing gear, enhancement of nets by "alarm" devices, and the acoustics of fishing gear. Pages 347-362 in Sensory Abilities of Cetaceans, Edited by J. Thomas and R. Kastelein. Plenum Press, New York..

Beard, J., P. Clapham, P. Hammond, S. Katona, F. Larson, J. Lien, D. Matilla, C. Mayo, N. Oien, P. Palsbol, T. Polacheck, J. Sigurjonsson, and T. Smith. 1990. YoNAH: Years of the North Atlantic Humpback Whale. International Whaling Commission, Scientific Committee. IWC/SC42/ 02. The Hague, Holland. 10 pages.

Bose, N., J. Lien, and J. Ahia. 1990. Measurements of the bodies and flukes of several cetacean species. Proceedings of the Royal Society of London. Series B, Biological Sciences 242(1305): 163-173.

Bose, N., and J. Lien. 1990. Energy absorption from ocean waves: A free ride for cetaceans. Proceedings of the Royal Society of London. Series B, Biological Sciences 240: 591-605.

Lien, J. 1991. The tragic tale of two marine parks. Borealis 2(3): 42-47.

Brennen, K. R., V. E. Baker, and J. Lien. 1991. A system for the transcutaneous recording of the cetacean electrocardiogram. Abstracts of the Ninth Biennial Conference on the Biology of Marine Mammals, Marine Mammal Society, Chicago, Illinois, 10.

Curren, K. C., N. Bose, and J. Lien. 1991. Use of track and wave data to determine possible wave energy absorption for whale propulsion. Abstracts of the Ninth Biennial Conference on the Biology of Marine Mammals, Marine Mammal Society, Chicago, Illinois 16.

Curren, K. C., N. Bose, and J. Lien. 1991. Do whales extract energy from ocean waves? Joutnal of the Marine Biology. Association of the U.K. 71(3): 733.

Nelson, D. L., and J. Lien. 1991. Behaviours of two Atlantic white-sided dolphins (Lagenorhynchus acutus) and their responses to objects. Abstracts of the Ninth Biennial Conference on the Biology of Marine Mammals, Marine Mammal Society, Chicago, Illinois 49.

Ostrom, P. H., S. A. Macko, and J Lien. 1991. An isotopic record from known age baleen. Abstracts of the Ninth Biennial Conference on the Biology of Marine Mammals, Marine Mammal Society, Chicago, Illinois 51.

Todd, S.K., J. Lien, and J. Y. Guigne. 1991. The acoustics of fishing gear: Implications for humpback whale entrapments in Newfoundland and Labrador. Abstracts of the Ninth Biennial Conference on the Biology of Marine Mammals, Marine Mammal Society, Chicago, Illinois 68.

Lien, J. 1991. A bibliography of selection and design criteria for protected natural areas. Report to the Protected Areas Association, St. John's, Newfoundland. 50 pages.

Lien, J., W. Barney, A. Verhulst, R. Seton, and S. Todd. 1991. Entrapments and strandings reported to the Entrapment Assistance Program during 1991. Report to the Department of Fisheries and Oceans - Newfoundland Region and the Newfoundland and Labrador Department of Fisheries. 29 pages.

Lien, J., R. Seton, and S. Todd. 1991. The impact of tour boats in the Witless Bay Ecological Reserve. Report to the Marine Adventures Association. 69 pages.

Lien, J., W. Barney, S. Todd, R. Seton, and J. Guzzwell. 1991. Tests of "whale alerts" on codtraps. Report to the Centre for Fisheries Innovation, St. John's, Newfoundland. 35 pages.

Lien, J., S. Todd, and J. Guigné. 1991. Inferences about perception in large cetaceans, especially humpback whales, from incidental catches in fixed fishing gear, enhancement of nets by "alarm" devices, and the acoustics of fishing gear. Pages 347-362 in Sensory Abilities in Cetaceans: Laboratory and Field Evidence. Edited by J. Thomas and R. Kastelein. Plenum Press, New York..

Nelson, D., A. Desbrosse, J. Lien, P. Ostrum, and R. Seton. 1991. A new stranding record of the pygmy sperm whale, Kogia breviceps, in waters off eastern Canada. Canadian Field-Naturalist 105(3): 407-408.

Nelson, D., and J. Lien. 1991. Status of the Long-finned Pilot Whale (Globicephla melas) in Canada. Report to Committee on the Status of Endangered Wildlife in Canada, Environment Canada, Ottawa.

Nelson, D., and J. Lien. 1991. Status of the White-beaked Dolphin in Canada. Report to Committee on the Status of Endangered Wildlife in Canada, Environment Canada, Ottawa.

Nelson, D., and J. Lien. 1991. Status of the northwestern Atlantic stock of Long-finned Pilot Whales. International Council for the Exploration of the Sea. Document WP1/91.

Lien, J. 1991. Occasional Paper 15 in Marine, Lake and Coastal Heritage. Edited by Robert Graham. http://www. fes.uwaterloo.ca/research/hrc/research/documents/HRC_ Consolidated_publication_list_2007.doc

Lien, J. 1992. Whales, fishermen and marine parks: Attitudes toward conserving and managing our ocean's resources. Pages 1-19 in Marine, Lake and Coastal Heritage, Edited by R. Graham. University of Waterloo Heritage Resources Centre, Waterloo, Ontario.

Lien, J. 1992. Eau Canada: Educating for change. Green Teacher (29) 15-16.

Lien, J. 1992. Need hands-on access to large whales? Report to the Office of Naval Research and National Marine Fisheries Service Workshop on Tagging and Tracking of Cetaceans. Arlie Foundation. 15 pages.

Lien, J., W. Barney, W. Ledwell, S. Todd, and K. Curren. 1992. Entrapments and strandings reported to the Entrapment Assistance Program during 1992. A preliminary report to the Department of Fisheries and Oceans and the Newfoundland and Labrador Department of Fisheries. 24 pages.

Lien, J., W. Barney, S. Todd, R. Seton, and J. Guzzwell. 1992. The effects of adding sounds to codtraps on the probability of collisions by humpback whales. Pages 701-708 in Marine Mammal Sensory Systems, Edited by J. A. Thomas, R. A., Kastelein, and A. Y. Supin. Plenum Press, New York.

Lien, J., J. Guigné, and S. Todd. 1992. Acoustical redesign of fixed nets and traps to minimize incidental catches of marine animals. Proceedings of the World Fisheries Congress, page 46 .

Lien, J., D. Nelson, S. Todd, and R. Seton. 1992. A program to minimize whale mortality and damage to fishing gear: Incidental catches of large whales in Newfoundland and Labrador. Proceedings of the World Fisheries Congress.

Lien, J., R. Seton, and S. Todd. 1992. Impact of tour boats in the Witless Bay Ecological Reserve on whales, seabirds, and people. A report to the Atlantic Canada Opportunities Agency and the Marine Adventures Association of Newfoundland and Labrador. 42 pages.

Lien, J., S. Todd, K. Curren, and R. Seton. 1992. The impact of tour boat activity on humpback whales and seabirds in the Witless Bay Ecological Reserve, Newfoundland, and effects of tour boat experiences on passengers. Report to the Marine Adventures Association and Atlantic Canada Opportunities Agency, St. John's, Newfoundland. 62 pages. 
Nelson, D., and J. Lien. 1992. A review of gear and animal characteristics responsible for incidental catches of cetaceans in fishing gear, along with proposed solutions. Proceedings of the World Fisheries Congress, Athens, Greece, May 3-8, 1992.

Ostrom, P. H., J. Lien, and S. A. Macko. 1992. Evaluation of the diet of Sowerby's beaked whale, Mesoplodon bidens, based on isotopic comparisons among northwestern Atlantic cetaceans. Canadian Journal of Zoology 71: 858-861.

Seton, R., J. Lien, D. Nelson, and P. Hann. 1992. A winter survey of marine mammals and birds on the south coast of Newfoundland. Report to the Atlantic Canada Opportunities Agency, Canadian Wildlife Service, and the Department of Fisheries and Oceans. 94 pages.

Seton, R., J. Lien, D. Nelson, and P. Hann. 1992. A survey of Blue Whales (Balaenoptera musculus), other cetaceans, seals, and marine birds on the south coast of Newfoundland, March 1992. Whale Research Group, Memorial University of Newfoundland. 68 pages.

Todd, S., J. Lien, and A. Verhulst. 1992. Orientation of humpback whales (Megaptera novaengliae) and minke whales (Balaenoptera acutorostrata) to acoustic alarm devices designed to reduce entrapment in fishing gear. Pages 727-739 in Marine Mammal Sensory Systems. Edited by J. A. Thomas, R. A. Kastelein, and A. Y. Supin. Plenum Press, New York.

Allen, J., P. Clapham, P. Hammond, S. Katona, F. Larsen, J. Lien, D. Mattila, N. Øien, P. Palsbøll, J. Sigurjonsson, and T. Smith. 1993. Years of the North Atlantic Humpback (YoNAH): Progress report. International Whaling Commission unpublished document SC/45/NA6.

Baker, C. S., A. Perry, J. L. Bannister, M. T. Weinrich, R. B. Abernethy, J. Calambokidis, J. Lien, R. H. Lambersen, J. Urbán Ramírez, O. Vasquez, P. J. Clapham, A. Alling, S. J. O'Brien, and S. R. Palumbi. 1993. Abundant mitochondrial DNA variation and world-wide population structure in humpback whales. Proceedings of the National Academy of Science USA 90: 8239-8243.

Curren, K., N. Bose, and J. Lien. 1993. Morphological variation in the harbour porpoise, (Phocoena phocoena). Canadian Journal of Zoology 71: 1067-1070.

Ketten, D. R., J. Lien, and S. Todd. 1993. Blast injury in humpback whale ears: Evidence and implications. Journal of the Acoustical Society of America 94(3): 1849-1850.

Lien, J. 1993. Student attitudes and how they are influenced. In Biology education and animals: Opportunities and issues. Edited by A. N. Rowan, and J. C. Weer. Tufts Center for Animals and Public Policy, Tufts University Press, North Grafton, Massachusetts.

Lien, J. 1993. A strategy for non-governmental organization involvement in the United Nations conference on highly migratory species and straddling stocks. Report to the Department of External Affairs and Fisheries and Oceans. 12 pages.

Lien, J. 1993. Fisheries Resource Conservation Council relations with non-traditional non-governmental organization interest groups. Report to the Fisheries Resource Conservation Council. 17 pages.

Lien, J., W. Barney, W. Ledwell, S. Stodd, P. Stevick, J. Huntingdon, R. Seton, and K. Curren. 1993. Incidental entrapments of marine mammals by inshore fishing gear reported in 1992, some result of bycatch monitoring, and tests of acoustic deterrents to prevent whale collisions in fishing gear. Report to Fisheries and Oceans Canada Newfoundland Region and the Newfoundland Labrador Department of Fisheries.
Lien, J., S. Todd, P. Stevick, F. Marques, and D. Ketten. 1993. The reaction of humpback whales to underwater explosions: Orientation, movements, and behaviour. Journal of the Acoustical Society of America 94(3): 1849.

Ostrom, P. H., J. Lien, and S. Macko. 1993. Evaluation of the diet of Sowerby's beaked whale, Mesoplodon bidens, based on isotopic comparisons among northwestern Atlantic cetaceans. Canadian Journal of Zoology 71: 858-861.

Volgenau, L., S. D. Kraus, and J. Lien. 1993. The impact of fishing gear entanglements on two substocks of the western north Atlantic humpback whale (Megaptera novaeangliae). Abstracts of the Tenth Biennial Conference on the Biology of Marine Mammals, Society for Marine Mammology 109.

Lien, J. 1993. Vessel-based education enrichment. Concept paper for the Council on Marine Education and the Newfoundland and Labrador Department of Education. 4 pages.

Baker, C. S., R. W. Slade, J. L. Bannister, R. B. Abernethy, M. T. Weinrich, J. Lien, R. Urban, P. Corkerton, J. Calmabokidis, O. Vasques, and S. R. Palumbi. 1994. Hierarchical structure of mitochondrial DNA gene flow among humpback whales, Megaptera novaeangliae, world-wide. Molecular Ecology 3(4):313-327.

Goff, G. P., J. Lien, G. B. Stenson, and J. Fretey. 1994. The migration of a tagged leatherback turtle, Dermochelys coriacea, from French Guiana, South America, to Newfoundland Canada in 128 days. Canadian FieldNaturalist 108(1): 72-73.

Lien, J. 1994. Entrapments of large cetaceans in passive inshore fishing gear in Newfoundland and Labrador (1979-1990). In: Gillnets and Cetaceans. Edited by W. F. Perrin, G.P. Donovan, and J. Barlow. International Whaling Commission Special Issue 15: 149-157.

Lien, J. 1994. Social and ethical responsibilities of scientists. The Scientist (12) 13

Lien, J. 1994. Experiments to reduce the incidental capture of Harbour Porpoise in groundfish gillnets in Grand Manan, Bay of Fundy. Report to the Department of Fisheries and Aquaculture, the Government of New Brunswick, and the Department of Fisheries and Oceans-ScotiaFundy Region. 20 pages.

Lien J., and C. Hood. 1994. An investigation of acoustic devices to prevent harbour porpoise by-catch in groundfish gillnets, and recommendations from fishermen in the Bay of Fundy for future by-catch mitigation. Report to the Department of Fisheries and Aquaculture, Fredericton, New Brunswick, and the Department of Fisheries and Oceans, Halifax, Nova Scotia.

Lien, J., and D. Nelson. 1994. The status of long-finned pilot whales in Canada. Report to International Council for the Exploration of the Sea. 9 pages.

Lien, J., D. Pittman, and D. Mitchell. 1994. Entrapments and strandings of cetaceans in Newfoundland and Labrador during 1993. Report to the Department of Fisheries and Oceans. 28 pages.

Lien, J., G. B. Stenson, S. Carver, S., and J. Chardine. 1994. How many did you catch? The effect of methodology on bycatch reports obtained from fishermen. Pages 535-540 in Gillnets and Cetaceans. Edited by G. Donovan, W.F. Perrin, and J. Barlow. International Whaling Commission Special Issue 15.

Nelson, D., and J. Lien. 1994. Behaviour patterns of two captive Atlantic white-sided dolphins, Lagenorhynchus acutus. Aquatic Mammals 20(1): 1-10. 
Nelson, D., and J. Lien. 1994. Responses of naive, captive dolphins to prototype whale alarms. Pages 621-622 in Gillnets and Cetaceans. Edited by W. Perrin, G. Donavan, and J. Barlow. International Whaling Commission Special Issue 15.

Shackell, N. L., and J. Lien. 1995. An under-utilized conservation option for fishery managers: Marine protected areas in the North-west Atlantic. Pages 21-30 in Proceedings of the Symposium on Marine Protected Areas and Sustainable Fisheries. Edited by N. L. Shackell and J. H. M. Willison. Second International Conference on Science and the Management of Protected Areas, Dalhousie University, Halifax, Nova Scotia. 16-20 May 1994.

Borggaard, D., and J. Lien. 1995. Reactions of individuallyidentified humpback whales to different types of industrial activity. Abstracts of the Eleventh Biennial Conference on the Biology of Marine Mammals, Marine Mammal Society 14.

Hood, C., J. Lien, and P. Y. Daoust. 1995. Lapsed time since death in harbour porpoise incidentally caught in groundfish gillnets. Abstracts of the Eleventh Biennial Conference on the Biology of Marine Mammals, Marine Mammal Society, 55.

Kastelein, R. A., A. D. Goodson, J. Lien, and D. de Haan. 1995. The effects of acoustic alarms on harbour porpoise (Phocoena phocoena) behaviour. Pages 157-167 in Harbour porpoises: Laboratory studies to reduce bycatch. P. E. Nachtigall,W.W.L. Au, J. Lien, and A. Read. De Spiel Publishers, Woerden, The Netherlands.

Lien, J. 1995. The role of environmental NGO's in the U.N. Conference on Straddling Fish Stocks and Highly Migratory Species. In Proceedings of the Workshop on the U.N. Straddling Stocks Conference. Memorial University of Newfoundland, St. John's, Newfoundland.

Lien, J. 1995. Conservation aspects of fishing gear: Cetaceans and gillnets. Pages 219-224 in Solving bycatch: Considerations for today and tomorrow. Edited by R. Dorfman and N. S. Dorfman. Alaska Sea Grant College Program Report Number 96-03, University of Alaska, Fairbanks.

Lien, J., and C. Hood. 1995. Treating fishermen as people: An effective approach to solutions of whale by-catch problems. Sixth International Symposium on Society and Resource Management, University Park, Pennsylvania, Pennsylvania State University.

Lien, J., C. Hood, D. Pittman, P. Ruel, D. Borggaard, C. Chisholm, L. Wiesner, T. Mahon, and D. Mitchell. 1995. Field tests of acoustic devices on groundfish gillnets: Assessment of effectiveness in reducing harbour porpoise by-catch. Pages 349-364 in Sensory Systems of Aquatic Mammals. Edited by R. A. Kastelein, J. A. Thomas, and P. E. Nachtigall. De Spil Publishers, Woerden, The Netherlands.

Lien, J., M. Morete, N. Brown, P. Hennebury, and K. Butler. 1995. An Acoustic Broom? Effects of high amplitude acoustic devices used as seal deterrents on large cetaceans. Abstracts of the Eleventh Biennial Conference on the Biology of Marine Mammals, Marine Mammal Society 69.

Lien J., D. Pittman, C. Hood, C. Richter, D. Borggaard, F. Marques, and S. Todd. 1995. Entrapments in fishing gear and strandings in Newfoundland and Labrador reported to the Entrapment Assistance Programme during 1994. A report to the Department of Fisheries and Oceans and the Atlantic Fisheries Adjustment Program. Memorial University of Newfoundland, St. John's, Newfoundland.
Lien, J., D. G. Taylor, and D. Borggaard. 1995. Management of underwater explosions in areas of high whale abundance. Proceedings of the International Conference on Technologies for Marine Environment Preservation (MARIEN V '95), Volume 2: 627-632.

Marques, F., and J. Lien. 1995. Spatial and temporal patterns of baleen whale habitat use in Placentia Bay, Newfoundland. Abstracts of the Eleventh Biennial Conference on the Biology of Marine Mammals, Marine Mammal Society, 72.

Nachtigall, P. E., J. Lien, W. W. L. Au, and A. J. Read. 1995. Harbour porpoises: Laboratory studies to reduce bycatch. De Spil Publishers, Woerden, The Netherlands, 168 pages.

Nelson, D., and J. Lien. 1995. Analysis of patterns of incidental entrapments of cetaceans in fixed fishing gear. Proceedings of the World Fisheries Congress.

Todd, S., P. Ostrom, and J. Lien. 1995. The use of isotope ratios in foraging studies of humpback whales. Abstracts of the Eleventh Biennial Conference on the Biology of Marine Mammals, Marine Mammal Society, 115.

Todd, S., P. Stevick, J. Lien, F. Marques, and D. Ketten. 1995. Behavioral effects of exposure to underwater explosions in humpback whales (Megaptera novaeangliae). Canadian Journal of Zoology 74: 1661-1672.

Volgenau, L., S. D. Kraus, and J. Lien. 1995. The impact of entanglements on two substocks of the western North Atlantic humpback whale, Megaptera novaeangliae. Canadian Journal of Zoology 73: 1689-1698.

Baird, R. W., D. Nelson, J. Lien, and D. W. Nagorssen. 1996. The status of the Pygmy Sperm Whale (Kogia breviceps) in Canada. Canadian Field-Naturalist 110: 525-532.

Hai, D. J., J. Lien, D. Nelson, and K. Curren. 1996. A contribution to the biology of the white-sided dolphin, Lagenorhychus albirostris, in waters off Newfoundland. Canadian Field Naturalist 110(2): 278-287.

Hood, C., J. Lien, and P. Y. Daoust. 1996. Ocular fluid analysis in harbour porpoise as a potential technique for determining postmortem interval. Bulletin of the Canadian Socociety of Zoologists 27(2): 65.

Lien, J. 1996. Creating protected marine areas in the new ocean. Marine Protected Areas Strategies in British Columbia, Parks Canada, Vancouver, Brirish Columbia.

Lien, J. 1996. A review of present knowledge of collisions with fishing gear and the use of sound to prevent or reduce the entanglement of large cetaceans in fixed fishing nets and traps, and comments on working with fishermen on marine mammal problems: Active acoustic solutions to cetacean by-catch. U.S. Marine Mammal Commission, Washington, D.C.

Lien, J. 1996. Conserving ocean resources: A scrutiny on the Bounty. Ecos 17(1): 16-20.

Lien, J., and D. Pittman. 1996. A survey of mussel growers in the Atlantic provinces: Predation by diving ducks on mussel beds. Report to the Atlantic Canada Shellfish Growers and the Canadian Centre for Fisheries Innovation. 10 pages.

Lien, J., S. K. Todd, and D. Pittman. 1996. Entrapments in fishing gear and strandings in Newfoundland and Labrador reported to the Entrapment Assistance Program during 1995. Report to the Department of Fisheries and Oceans and the Newfoundland and Labrador Department of Food, Fisheries, and Agriculture. 10 pages.

Nelson, D., and J. Lien. 1996. The status of the long-finned pilot whale, Globicephala melas, in Canada. Canadian Field-Naturalist 110(3): 511-524. 
Nelson, D., and J. Lien. 1996. Status report on the longfinned pilot whale Globicephala melas. Committee on the Status of Endangered Wildlife in Canada, Ottawa. 46 pages.

Richter, C., and J. Lien. 1996. A report to groundfish gillnet fishermen in the Bay of Fundy on the impact of acoustic alarms designed to reduce harbour porpoise by-catches on fish species. Report to the Department of Fisheries and Oceans-Scotia/Fundy and the Fishermen's Association of the Bay of Fundy. 10 pages.

Richter, C. J., J. Lien, and C. Hood. 1996. Effectiveness of active, acoustic devices in reducing harbour porpoise bycatch in groundfish gillnets in the Bay of Fundy. Bulletin of the Canadian Society of Zoologists 27(2): 92.

Todd, S. K., P. Ostrom, and J. Lien. 1996. Carbon and nitrogen stable isotope ratios suggest potential seasonal and annual diet changes in humpback whales (Megaptera novaeangliae). Bulletin of the Canadian Society of Zoologists 27(2): 101 .

Trippel, E. A., M. B. Strong, C. Hood, C. Richter and J. Lien. 1996. By-catch of harbour porpoise (Phocoena phocoena) in the lower Bay of Fundy gillnet fishery in 1995. Canadian Science Advisory Secretariat, Atlantic Fisheries Research Document 1996/110.

Lien, J. 1997. Foundation fisheries. Report to the Fisheries Resource Conservation Council. 5 pages.

Lien, J., and P. Hennebury. 1997. You can fool all of the ducks some of the time; you can fool some of the ducks all of the time; but you can't fool all of the ducks all of the time: An investigation of diving duck predation on farmed mussels, and evaluation of a harassment procedure to minimize it. Report for the Department of Agriculture, Fisheries and Forestry, Government of PEI and the Department of Fisheries, Government of Nova Scotia. 69 pages.

Lien, J., P. Hennebury, and D. Pittman. 1997. The use of harassment and acoustic deterrents to minimize predation by diving ducks on mussel farms. Report to the Nova Scotia and Prince Edward Island Departments of Fisheries and the Canadian Centre for Fisheries Innovation. 35 pages.

Lien, J., D. Pittman, and C. Nordeen. 1997. An evaluation of effects of high amplitude sounds in the marine environment. Report to the Canadian Centre for Fisheries Innovation, Airmar Corporation, and Fundy Aquaculture. 30 pages.

Palsbøll, P. J., J. Allen, M. Bérubé, P. J. Clapham, T. P. Feddersen, P. S. Hammond, R. R. Hudson, H. Jørgensen, S. Katona, A.H. Larsen, F. Larsen, J. Lien, D. K. Mattila, J. Sigurjónsson, R. Sears, T. Smith, R. Sponer, P. Stevick, and N. Øien. 1997. Genetic tagging of humpback whales. Nature 388: 767-769.

Todd, S., P. Ostrom, J. Lien, and J. Abrajano. 1997. Use of biopsy samples of humpback whale (Megaptera novaeangliae) skin for stable isotope $\left(\delta^{13} \mathrm{C}\right)$ determination. Journal of Northwest Atlantic Fishery Science 22: 71-76.

Curren, K., and J. Lien. 1998. Observations of White Whales, Delphinapterus leucas, in waters off Newfoundland and Labrador and in the Gulf of St. Lawrence, 19791991. Canadian Field-Naturalist 112(1): 28-31.

Daoust, P.-Y., J. Lien, and A. Knowlton. 1998. Bowhead whale (Balaena mysticetus) stranding on the northeast coast of Newfoundland. Canadian Cooperative Wildlife Health Centre Newsletter Volume 5-3.

Furtado-Neto, M. A. A., C. Monteiro-Neto, A. A. Campos, J. Lien, and S. M. Carr. 1998. Are northern-hemisphere humpback whales stranding in South Atlantic beaches? Answers from mitochondrial DNA sequences. Abstract of the VIII Reunião de Trabalho de Especialistas em Mamíferos Aquáticos.

Lien, J. 1998. The Eastport Lobster Conservation Strategy. Sea Wind 14(2): 116-119.

Lien, J. 1998. Social sciences and marine biodiversity conservation. Report to the Social Science and Humanities Research Council. 9 pages.

Lien, J., B. Lane, N. Gribble, and G. McPherson. 1998. Use of acoustic alarms to reduce humpback whale and bycatch in shark control gillnets on Queensland's Gold Coast. In Shark management and conservation. Edited by N. A. Gribble, G. McPherson, and B. Lane. Proceedings from the sharks and man workshop of the Second World Fisheries Congress, Brisbane, Australia, 2 August 1996. Queensland: Department of Primary Industries.

Mackay, D., A. Monsour, and J. Lien. 1998. Reproductive status of whales and seals determined by analysis of hormone ratios in biopsies obtained in field studies. President's Research Fund proposal, Memorial University of Newfoundland, St. John's, Newfoundland.

Neto, C. M., and J. Lien. 1998. Acoustic devices on gillnets: A viable solution to reduce the mortality of dolphins in Ceara State, Brazil. Report to the Government of Ceara. 6 pages.

Harvey, T., and J. Lien. 1998. Prevention of oiled wildlife. Report to the Canadian Coast Guard, Department of Fisheries and Oceans, and Department of the Environment. 36 pages.

Canada Coast Guard. 1999. Prevention of Oiled Wildlife. Report to Minister of Fisheries and Oceans, Transport and Environment, Canadian Coast Guard, St. John's, Newfoundland and Labrador.

Borggaard, D., J. Lien, and P. Stevick. 1999. Assessing the effects of industrial activity on large cetaceans in Trinity Bay, Newfoundland (1992-1995). Aquatic Mammals 25(3): 149-161.

Eckert, S. A., and J. Lien. 1999. Recommendations for eliminating incidental capture and mortality of Leatherback Turtles (Dermochelys coriacea) by commercial fisheries in Trinidad and Tobago. Report to the Wider Caribbean Sea Turtle Conservation Network (WIDECAST). HubbsSea World Research Technical Report Number 2000-310. 7 pages.

Lien, J. 1999. When marine conservation efforts sink: What can be learned from the abandoned effort to examine the feasibility of a National Marine Conservation Area on the NE Coast of Newfoundland? Canadian Council on Ecological Areas (CCEA) 16th Conference, Ottawa, Canada, October 4-6, 1999.

Lien, J. 1999. Lien report: A review of live-capture and captivity of marine mammals in Canada. Department of Fisheries and Oceans, Ottawa, Ontario.

Reeves, R. R., C. Smeenk, C. C. Kinze, R. L. Brownell, and J. Lien. 1999. White-beaked Dolphin Lagenorhynchus albirostris (Gray, 1846). Pages 1-30 in Handbook of Marine Mammals, Volume 6: The Second Book of Dolphins and the Porpoises. Edited by S. H. Ridgway and S.R. Harrison. Academic Press, San Diego. Pages 1-30.

Smith, T. D., J. Allen, P. J. Clapham, P. S. Hammond, S. Katona, F. Larsen, J. Lien, D. Mattila, P. J. Palsbøll, J. Sigurjónsson, P. T. Stevick, and N. Øien. 1999. An oceanbasin-wide mark-recapture study of the North Atlantic Humpback Whale (Megaptera Novaeangliae). Marine Mammal Science 15(1):1-32. 
Ledwell, W., J. Huntington, and J. Lien. 2000. Whale entrapments in fishing gear and other marine animal incidental entrapments during 2000. Technical report, Habitat Stewardship Program of Environment Canada.

Lien, J. 2000. In the face of disaster - Science for people and nature. Pages 45-53 in Coastal Zone Canada '98, Coastal Challenges: Sharing Our Experiences — Building Our Knowledge. Edited by J. D. Pringle, C. A. Wright, and M. W. Dunn. Coastal Zone Canada British Columbia Association, Victoria, British Columbia Canada.

Lien, J. 2000. A history of the Entrapment Assistance Programme in Newfoundland and Labrador (1978-2000). Proceedings of the Whales 2000, $7^{\text {th }}$ International Conference of the American Cetacean Society, Monterey, California.

Lien, J. 2000. The conservation basis for the regulation of whale watching in Canada by the Department of Fisheries and Oceans: a precautionary approach. Department of Fisheries and Oceans.

Lien, J., and M. Dunn. 2000. Troubled waters: The status of wildlife habitats in Canada's oceans and coasts. Technical Report 5, Wildlife Habitat Canada. 108 pages + appendices.

Lien, J., and M. Dunn. 2000. Observations on developing a framework to assess the Department of Fisheries and Oceans' implementation of aquatic habitat management objectives. Report for the Department of Fisheries and Oceans and Wildlife Habitat Canada, Ottawa, Ontario. 28 pages.

Lien, J., and T. Harvey. 2000. The Entrapment Assistance Programme: 1999. Report to the Canadian Coast Guard and the Department of Fisheries and Oceans. St. John's, Newfoundland. 13 pages.

Lien, J., and C. Hood. 2000. Thoughts on reduction of seabird bycatch in fishing gear based on experiences in mitigation of cetacean bycatch by fisheries: Understanding both animals and fishermen. In Workshop on Seabird Incidental Catch in the Waters of Arctic Countries. Edited by J. W. Chardine, J. M. Porter, and K. D. Wohl. Conservation of Arctic Flora and Fauna Technical Report Number 7, Iceland.

MacPherson, G., J. Lien, and N. Gribble. 2000. An inexpensive alarm to prevent humpback collisions with meshes. In Proceedings of Humpbacks - 2000. August 31-3 September, Queensland Museum, Brisbane, Queensland, Australia. Memoirs of the Queensland Museum 47(2).

Corbelli, C., and J. Lien. 2001. A preliminary study of the impact of whales watching activity on humpback whales in Witless Bay, Newfoundland. The Osprey 12 00-00

Lien, J. 2001. Whale, shark, and turtle entrapments in fishing gear in Newfoundland and Labrador during 2000. Report to the Department of Fisheries and Oceans. 5 pages.

Lien, J. 2001. Leatherback Turtle bycatch distribution (19792000). Report for the Leatherback Turtle Review, Species at Risk Act Secretariat, and the Department of Fisheries and Oceans. 8 pages.

Lein, J. 2001. Harbour Porpoise by-catch in Newfoundland. Report to Harbour Porpoise Review, Species at Risk Act Secretariat, and the Department of Fisheries and Oceans. 12 pages.

Lein, J. 2001. Mitigation of Harbour Porpoise bycatch. Report to Harbour Porpoise Review, Species at Risk Act Secretariat, and the Department of Fisheries and Oceans. 4 pages.

Harris, L., and J. Lien. 2001. A review of the White Rose offshore petroleum project. White Rose Public Inquiry,
Department of Mines and Energy, Government of Newfoundland and Labrador, St. John's, Newfoundland. 17 pages.

Lien, J. 2001. The conservation basis for the regulation of whale watching in Canada by the Department of Fisheries and Oceans: A precautionary approach. Canadian Technical Report of Fisheries and Aquatic Sciences 2363. 24 pages.

Lien, J. 2001. The growth of the commercial whale watching industry in Canada and a code of conduct for tour boats in Newfoundland and Labrador. The Osprey 12: 10-14.

Lien, J. 2001. Trends in tourism and ecological protection. Pages 20-21 in Sustainable Tourism. Edited by R. Hingston. Parks Canada, Ottawa, Ontario.

Lien, J., D. Nelson, and D. J. Hai. 2001. Status of the WhiteBeaked Dolphin Lagenorhynchus albirostris, in Canada. Canadian Field-Naturalist 115(1): 118-126.

Matilla, D. K., J. Allen, P. J. Clapham, N. Friday, P. S. Hammond, S. Katona, F. Larsen, J. Lien, P. J. Palsboll, J. Robbins, J. Sigurjonsson, T. D. Smith, P. T. Stevick, G. Vikingsson, and N. Oien. 2001. Recent findings concerning the migration and breeding ground composition of North Atlantic Humpback whales. In Proceedings of Humpbacks - 2000, August 31-3 September Queensland Museum, Brisbane, Queensland, Australia, Memoirs of the Queensland Museum 47 (2)

McPherson, G. R., J. Lien, N. A. Gribble, and B. Lane. 2001. Review of an acoustic alarm strategy to minimise bycatch of humpback whales in Queensland coastal gill net fisheries. Memoirs of the Queensland. Museum 47(2): 499-506.

Nordeen, C., and J. Lien. 2001. The effects of high amplitude acoustic deterrents on the abundance and distribution of baleen whales (abstract only). Abstracts of the Biennial Meeting of the Marine Mammal Society, Vancouver, British Columbia.

Palsbøll, P. J., J. Allen, T. H. Anderson, M. Bérubé, P. J. Clapham, T. P. Feddersen, N. Friday, P. Hammond, H. Jørgensen, S. K. Katona, A. H. Larsen, F. Larsen, J. Lien, D. K. Mattila, F. B. Nygaard, J. Robbins, R. Sponer, R. Sears, J. Sigurjónsson, T. D. Smith, P. T. Stevick, G. Vikingsson, and N. Øien. 2001. Stock structure and composition of the North Atlantic humpback whale, Megaptera novaeangliae. Paper SC/53/NAH11 presented to the International Whaling Commission Scientific Committee. Available from IWC, 135 Station Road, Impington, Cambridge, UK.

Ross, B. P., J. Lien, and R. W. Furness. 2001. Use of underwater playback to reduce the impact of eiders on mussel farms. ICES Journal of Marine Science, 58: 517-524.

Collins, R. K., and J. Lien. 2002. In our own hands: Community-based lobster conservation in Newfoundland (Canada). Biodiversity 3(2): 11-14.

Lien, J., C. Hood, W. Ledwell, and C. Corbelli. 2002. More strandings of Sowerby's Beaked Whales on Newfoundland's Northeast Coast. The Osprey 33:1, St. John's, Newfoundland.

Lien, J., H. Whitney, W. Ledwell, P. Y. Daoust, and B. Sjaer. 2002. A New Record of a Pigmy Sperm Whale, Kogia breviceps, in Newfoundland. The Osprey 33: 4, St. John's, Newfoundland.

Ledwell, W., J. Huntington, and J. Lien. 2002. Whale entrapments in fishing gear and a summary of the Marine Animal Disentanglement Assistance Program in Newfoundland and Labrador during 2002. Report for the Habitat Stewardship Program of Environment Canada. 11 pages. 
Lien, J. 2002. Book review: Monsters of the Sea: the History, Natural History, and Mythology of the Ocean's Most Fantastic Creatures, and the Search for the Giant Squid. Newfoundland Studies 16(2) 276-279.

Monseur, A., D. McKay, J. Lien, J. Banoube, N. Øien, and G. Stenson. 2002. Determination of pregnancy status from blubber samples in Minke Whales (Balaenoptera acutorostrata). Marine Mammal Science 18(1): 112-120.

Hood, C., P. Y. Daoust, J. Lien, and C. Richter. 2003. An experimental study of postmortem ocular fluid and core temperature analysis in incidentally captured harbour porpoise (Phocoena phocoena). North Atlantic Marine Mammal Commission Scientific Publication 5:229-242.

Stenson, G., J. Lien, J. Lawson, and R. Seton. 2003. Ice entrapments of Blue Whales in Southwest Newfoundland: 1868-1992. Pages 15-17 in Proceedings of the workshop on the development of research priorities for the northwest Atlantic blue whale population, 20-21 November 2002. Edited by V. Lesage and M. Hammill. Fisheries and Oceans Canada, Canadian Science Advisory Secretariat, proceeding series 2003/031.

Stevick, P. T., J. Allen, M. Bérubé, P. J. Clapham, S. K. Katona, F. Larsen, J. Lien, D. K. Mattila, P. J. Palsbøll, J. Robbins, J. Sigurjónsson, T. D. Smith, N. Øien, and P. S. Hammond. 2003. Segregation of migration by feeding ground origin in North Atlantic humpback whales (Megaptera novaeangliae). Journal of Zoology 259(3): 231-237.

Stevick, P. T., J. Allen, P. J. Clapham, N. Friday, S. K. Katona, F. Larsen, J. Lien, D. K. Matilla, P. J. Palsbøll, J. Sigurjónsson, T. D. Smith, N. Øien, and P. S. Hammond. 2003. North Atlantic humpback whale abundance and rate of increase four decades after protection from whaling. Marine Ecology Progress Series 258: 263-273.

McPherson, G. R., D. Ballam, J. Stapley, S. Peverell, D. H. Cato, N. Gribble, C. Clague, and J. Lien. 2004. Acoustic alarms to reduce marine mammal bycatch from gillnets in Queensland waters: Optimising the alarm type and spacing. Proceedings of Acoustics 2004, November 3-5, 2004, Gold Coast, Australia.

Martins A. M. A., T. T. Alves-Junior, M.A. A. FurtadoNeto, and J. Lien. 2004. The most northern record of Gervais' beaked whale, Mesoplodon europaeus (Gervais, 1855), for the southern hemisphere. Latin American Journal of Aquatic Mammals 3: 151-155.

Monteiro-Neto, C., F. J. C. A, Vila, T. T. Alves-Jr, D. S. Araüjo, A. A. Campos, A. M. A. Martins, C. L. Parente, A. Manuel, R. Furtado-Neto, and J. Lien. 2004. Behavioral responses of Sotalia fluviatilis (Cetacea, Delphinidae) to acoustic pingers, Fortaleza, Brazil. Marine Mammal Science 20(1): 145-151.

Ledwell, W., J. Lien, and D. Wareham. 2005. A possible ship collision with a Sowerby's beaked whale (Mesoplodon bidens) that stranded in Conception Bay, Newfoundland. The Osprey 36: 4

Stevick, P. T., J. Allen, P. J. Clapham, S. K. Katona, F. Larsen, J. Lien, D. K. Mattila, P. J. Palsbøll, R. Sears, J. Sigurjónsson, T. D. Smith, G. Vikingsson, N. Øien, and P. S. Hammond. 2006. Population spatial structuring on the feeding grounds in North Atlantic humpback whales (Megaptera novaeangliae). Journal of Zoology 270(2): 244 255.

McAlpine, D., M. C. James, J. Lien, and S. A. Orchard. 2007. Status and conservation of marine turtles in Canadian waters. Pages 85-112 in Ecology, Conservation and
Status of Reptiles in Canada. Edited by C. N. L. Seburn and C. A. Bishop. Herpetological Conservation 2. Canadian Amphibian and Reptile Conservation Network, Ottawa.

Lien, J. 2008. Entrapment and Entanglement. Pages 391-392 in Encyclopedia of Marine Mammals, Second edition. W. F. Perrin, B. Würsig, and J. G. M. Thewissen. Academic Press, San Diego.

\section{Patents}

"Whale Alert", Acoustic deterrent to keep whales out of fishing nets. Patents held with J. Guigne, J. Guzzwell, C-CORE, NewTech in Canada, U.S.A. and Australia.

\section{Books and Guides}

Lien, J., (with N. Hennessey). 1982. Whales of Newfoundland and Labrador. M.U.N. Press, St. John's, Newfoundland, 44 pages,

Lien, J., (with others of the Whale Research Group M.U.N.) 1984. Getting Along: Enrichment Kit Teacher's Guide. Department of Education, Government of Newfoundland and Labrador, St. John's, Newfoundland, 45 pages.

Lien, J., (with others of the Whale Research Group M.U.N.) 1984. Getting Along: Teacher's Guide. (with others of the Whale Research Group - M.U.N.) Breakwater Books, St. John's, Newfoundland, 88 pages. (Curricula for fifth grade)

Lien, J., L. Fawcett, and S. Staniforth. 1985. Wet and Fat: Whales and Seals of Newfoundland and Labrador. Breakwater Books. St. John's, Newfoundland. 136 pages. (2nd printing 1988).

Lien, J., with R. Graham. Editors. 1985. Marine Parks and Conservation: Challenge and Promise, Volume I: Issues. Harkin Park Book Series Number 10., National and Provincial Parks Association of Canada, Toronto, Ontario, 254 pages.

Lien, J., with R. Graham. Editors. 1985.Marine Parks and Conservation: Challenge and Promise, Volume II: International Experience. Harkin Park Book Series Number 11. National and Provincial Association of Canada, Toronto, Ontario, 212 pages. 5.

Lien, J., with H. Walter. 1987. Life along the edge: Where land and sea interact. Teacher's guide for curricula for Grade 4-6. Parks Canada, Ottawa, 62 pages.

Popular Articles/Educational Materials (since 1985 only) Conservation of wilderness and wildlife to preserve our traditional way of life. Evening Telegram, St. John's, Newfoundland 7 December 1985.

What's the moose capital of Canada? (with B. Stirling) Nature Canada, 15 (2) 8-9, 1986.

Fishermen and whales: getting along. The Whale Watcher, 20 (1), 1986.

1986 Fishery Management Calendar (with H. Walter, Tamura Goodwin, Judy Au) Published in full page monthly instalments in the Evening Telegram, St. John's, Newfoundland, 1986.

Fishermen's Calendar: 1987 Robinson-Blackmore, St. John's, Newfoundland.

Book Review on The War Against the Seals: A history of the North American Seal Fishery by Briton Cooper Busch. The Evening Telegram, 21 February 1987, pages 1A \& A4. Avalon Marine Guide [with Frances Barry) Published by Bird Island Charters and the Canadian Park Service, 1988. 
Search the Sea: Evaluating a marine display for children (with J. Dodd) Eau Canada 4 (1) 3-12, 1987.

A whale of a tale: Following the sea and whalers no more (with N. Bose) Evening Telegram, 6 February 1988.

Establishing Marine Parks: New efforts in public education and information programs, Park News. 1988.

The future of Oceans: A review. Evening Telegram, 20 February 1988.

Fisherman's Calendar: 1988 Robinson-Blackmore, St. John's, Newfoundland.

Fisherman's Calendar: 1989 Robinson-Blackmore, St. John's, Newfounland.

Lien, J. 1989. A junk food diet for sperm whales! Atlantic Fishermen, pages?.

Lien, J., F. Chopin, and J. Huntington. 1989. Relict fishing gear effects whales. Fishing News International, August, 57.

Lien, J. 1989. The big whales are in big trouble. Outdoor Canada, Summer, page 20.

Lien J., and W. Ledwell. 1989. Continued development of the first North American colony of Manx Shearwaters. The Osprey, 94-95.

Wright, D., and J. Lien. 1989. Whales of the Gulf of St. Lawrence and Quebec. Poster published by the Linnean Society, Montreal.

Lien, J., G. B. Stenson, and G. Goff.1989. Marine Turtle Education Programs. Marine Turtle Newsletter 45: 3-5.

Lien, J., G. B. Stenson, and G. Goff. 1989 Working With Fishermen in the Northwest Atlantic. Marine Turtle Newsletter 5: 13-15.

Identification Guides to whales, seals, birds and sharks. [with Dawn Nelson]. Published jointly by Canadian Wildlife Service, Fisheries and Oceans and Memorial University of Newfoundland.

Whales and Seals of Newfoundland and Labrador. [with D. Nelson]. Memorial University of Newfoundland, St. John's, Newfoundland.

Fisherman's Calendar: 1991, Fisheries and Oceans, St. John's, Newfoundland.

Fisheries Calendar - 1992, Fisheries and Oceans, St. John's, Newfoundland.
A Teacher's Guide to the 1992 Fisheries Calendar, (with D. Nelson) Memorial University of Newfoundland, St. John's, Newfoundland

Marine Fact Sheet Series, Memorial University of Newfoundland and Department of Fisheries and Oceans (Canada), St. John's, Newfounland.

Fisheries Calendar - 1993, Fisheries and Oceans, St. John's, Newfoundland.

Whale Fact Sheets [with D. Nelson)] Memorial University of Newfoundland, St. John's

Lien, J. 1993. On the urgent need to protect oceans. World Wildlife Fund Newsletter, Invited editorial.

Lien, J. 1993. The Fisheries Resource Conservation Council. Beyond the Banks, 1 (3), 2-3.

Lien, J. 1994. Fishermen as environmental refugees. Eco 2 (87), 3-4.

Fisheries Calendar - 1994, Fisheries and Oceans, St. John's, Newfoundland.

What difference do you make? Marine Adventures Association Newsletter, 149 New Gower Street, St. John's, Newfoundland.

Lien, J. 1998. The National Marine Conservation Area Feasibility Study. Evening Telegram

Lien, J., B. Chubs, J. Squires, and A. Hart. 1999 Conservation Calendar.

Lien, J. 1999. Kill a seal for Jesus - A comment on John Efford's campaign. Evening Telegram. St, John's, Newfoundland.

Series of posters including Whales of Newfoundland, Seals of Newfoundland and Labrador, The Basking Shark and Sharks of Newfoundland, Seabirds of Newfoundland, Common Inshore Fishing Gear, The Capelin, Common Whales of Newfoundland and Labrador, Whale Tails of Newfoundland and Labrador. Educational series with Don Wright. [To 1989 over 500,000 published and distributed through Fisheries and Oceans and The Newfoundland and Labrador Department of Education. To 1999 over one million had been published].

[Lien, J.] Monthly column in Portugal Cove/St. Phillips Times under pseudonym "Gammel Ost". 